ISSN : 2641-1446 (Online) ISSN :2356-2404 (Print)

Homepage: https://journal.uir.ac.id/index.php/jshmic

Vol 9, No 1, February 2022

\title{
Investigating Students' Listening Skill Using Liveworksheet as an Outline Teaching Platform
}

\author{
Nurul Hidayah ${ }^{1}$, Slamet Asari ${ }^{2}$ \\ Universitas Muhammadiyah Gresik ${ }^{1,2}$ \\ nurulhidayah_180403;@umg.ac.id; asari70@umg.ac.id
}

\begin{abstract}
This study aimed to determine the students' listening skill ability and perspectives through liveworksheet platform. The COVID-19 pandemic has impacted education, so we need suitable media, especially for listening skills; one of the right platforms is liveworksheets. Liveworksheet provides many convenient features and a creative, innovative, and interactive platform in which there is an added interest for online learning to activities that show their listening skills ability. This study uses a quantitative method, and uses questionnaires also test survey instruments. The participants of this study were 52 students grade 2 at Ban KaengSriphum Junior High School, Loei, Thailand. The results showed that from the pre-test and post-test, liveworksheet can help student to their listening skill ability. Then, 50.9\% of students strongly agree that listening lessons are essential, $43.4 \%$ strongly agree that the liveworksheet is an effective platform, $44.2 \%$ strongly agree that the platform needs to be maintained, $43.4 \%$ strongly agree that liveworksheets are the expected media, and 39.6\% of students strongly agree that liveworksheets are easy to reach media for listening skills. From these results, it can be said that liveworksheets platform can help students in listening skills ability.
\end{abstract}

\section{KEYWORDS \\ students' perspective; liveworksheet; listening skill ability}


Nurul Hidayah ${ }^{1}$, Slamet Asari ${ }^{2}$

J-SHMIC : Journal of English for Academic

Vol 9, No 1, February 2022

\begin{abstract}
Kemudian, 50,9\% siswa sangat setuju bahwa pelajaran mendengarkan itu penting, 43,4\% sangat setuju bahwa liveworksheet adalah platform yang efektif, 44,2\% sangat setuju bahwa platform perlu dipertahankan, 43,4\% sangat setuju bahwa liveworksheet adalah media yang diharapkan, dan 39,6\% siswa sangat setuju bahwa liveworksheet merupakan media yang mudah dijangkau untuk keterampilan menyimak. Dari hasil tersebut, dapat dikatakan bahwa platform liveworksheets dapat membantu siswa dalam kemampuan keterampilan menyimak.
\end{abstract}

\title{
INTRODUCTION
}

The Covid-19 pandemic has impact changes in all aspects of life, especially in the world of education around the world. During this pandemic, learning occurs, as usual, but in a different place and access to knowledge. The principle of this home learning activity is that students can access learning materials and resources without space and time constraints. This home learning activity is expected to support learning activities limited in space and facilitate material delivery to students. The change in the implementation of learning which was originally face-to-face learning at school to online learning, is carried out at home. However, there are challenges from the flexibility of online learning in this limited space, one of which is the readiness of teachers and students to carry out learning from home. Gusty (2020) explained that the facilities and infrastructure owned by schools and students as a whole were stated to be not ready to carry out online learning quickly and precisely.

However, the patience of the entire community, from teachers to students, is a significant factor in the success of online learning during the Covid-19 pandemic (Arief, 2020). In addition, online learning also needs to pay attention to the psychological condition of students while studying from home. In this case, the teacher is required to be able to manage each component of learning well so that learning objectives can be implemented. In addition, other problems occur in online learning activities, such as network constraints, the availability of gadgets, and the current mastery of technology. In addition to creative and innovative methods and media. It is used to determine students' ability to understand the material and measure learning outcomes.

In today's online learning, providing exciting activities for students is something that teachers must pay attention to. Teachers have a strong demand for using internet information technology as a means of application in the teaching process in the classroom to help students cope with their learning to improve learning. Listen to English. Four skills must be taught to master language learning: listening, speaking, reading, and writing. Of course, the learning process begins with listening, speaking, reading, and the last is writing. Man cannot speak until he listens. Nor (2014) report that listening is the essence of all aspects that will be obtained by someone, especially for learning a language. By listening, a person can produce writing, reading, and speaking skills.

Listiyaningsih (2017) said that listening is a skill that must be mastered in language learning, with listening skills the listener can catch and digest speech well. Listening to means distinguishing sounds, understanding vocabulary, grammar, interpreting intonation and meaning, considering everything simultaneously, and adapting to the socio-cultural context of the expressions heard (Vandergrift, 2012). Therefore, practical techniques and methods are needed in teaching listening skills so that students can listen to and understand well. That needs to be supported by the use of technology to facilitate online learning today. As explained by educational technology scholars, to measure and test learning outcomes critically and have 
a high level of criticism, it is necessary to emphasize the use of technology (Fournier, 2011) because technology is a tool that can be used to create meaningful experiences in the teaching and learning process. At the same time, a video is a tool that is often used for the online learning process because, with the video, students can easily digest the material presented.

Hubbard (2010) provided participants with a listening training program that included collaborative training and discussions on the use of applications and skills and steps for success. This is used so that particular learning objectives and reasons can be appropriately achieved. Integration of online technology systems into the environment to make it easier for students and teachers, especially for parents who are less likely to collaborate, assist, exchange information, or evaluate student results online learning. Therefore, advances and the uniqueness of technology are needed in this era of online learning, such as applications and platforms that can attract students' interest in the learning process. One of the platforms used for junior high school students with such a learning model is a live worksheet. Liveworksheet is a web-based platform that provides alternative media for delivering material in the form of live worksheets that can be accessed and responded to by students online in this school because they lack in listening skill, so they need an attracktive media to motivated their listening skill.

The delivery of learning on this platform is done by providing material in the form of teaching videos and assignments. After understanding the learning video that has been delivered, the collection of tasks can be done on the same day or another day if there are obstacles on the specified day. So, students can easily reaccess it if the next day they need it or have difficulty understanding it. In addition, one's perspective has changed from using traditional spreadsheets that need to be printed and created offline to spreadsheets that students can work on online without having to print, while still providing an attractive display and diverse activities, and can be accessed without time constraints.

The reality in this school is that listening skills are in a weak condition because the delivery method and the media used are still not proven by the very low listening scores, so students need media that attracts student interest in learning. So the author focuses on teaching listening by using video and audio visual through the live worksheet platform. This study aims to determine students' listening skills in using liveworksheet platform. Therefore, this research is a survey research with a test design that has been tested on students. The research survey aims to determine the population by expressing opinions, characteristics, and students' beliefs about something. While the test used to measure and determine the success of students' listening skills after using the liveworksheet.

Appropriate technology in its delivery can help students during learning from home. Technology is a tool that can be used to create meaningful experiences in the teaching and learning process. One technology that can be used is the liveworksheet.com platform, according to Flipped (2021). That is also evidenced by the fact that students tend to answer questions enthusiastically according to familiar topics given on liveworksheets, such as describing someone or talking about the most memorable moment they had. The learning videos contained on the platform can also be accessed at any time, especially if students do not understand the lesson; they can reaccess the video.

Saleh (2020) revealed that the results of several researchers showed that the use of live worksheets was more dominantly practiced by teachers than the media google form, zoom, google meet, Kahoot, and so on. Researchers believe that online learning platforms like liveworkseets.com provide effective learning similar to classroom learning. Giving the right topic, having a practical learning situation, knowing the orientation of learning objectives, and having good preparation can help students. That is indicated by the fact that students tend to enthusiastically respond to questions based on familiar topics provided on liveworksheets, such as describing someone or talking about their most memorable moment.

The research results of Mukti (2021) show that the liveworksheet platform is used as a medium for measuring student readiness to interact and gain knowledge with the liveworksheet. This online school allows students to shape and establish the character traits of each student. This study does not reflect the fear of mistakes because students like to learn without being influenced and pressured by other parties. Effectiveness has also been proven in all respects willingness to communicate by promoting students' communication skills and ultimately the mastery of their second language. However, there is one contributing factor that 
is more dominant. Several motivations have also been suggested to reduce students' anxiety and increase self-confidence.

From the relevant research results above, it can be concluded that the liveworksheet was declared victorious in helping to increase the effectiveness of student learning and facilitate understanding of the material. In contrast to previous research, this study explains students' perceptions of the use of the liveworksheet platform, which is considered to increase students' interest in listening activities to their exercise and exam scores. This platform is also a platform that is often used in online learning activities at schools.

\section{METHOD}

This quantitative research to examine how students perceive using the liveworksheet platform to their listening skills ability, the research participant was students conducted at Ban Kaeng Sriphoom Junior High School Loei, Thailand. The research targets were all 2nd-grade students with a total of 52 students consisting of 20 male students and 32 female students at Ban KaengSriphum Junior High School Thailand.. To express students' perspective of using the liveworksheet platform to their listening skills ability, the researcher used a questionnaire survey instrument (the effectiveness, preserved, accordance, and easy access) and a test that had been tested on students to obtain data. This quantitative data, obtained from the results of distributing questionnaires to students. The questionnaire used in this study used a Likert scale with four categories (strongly agree, agree, disagree, and disagree). Furthermore, the questionnaire was used to evaluate and consider the impact of using liveworksheets in students' listening skills ability. The researcher made this questionnaire by himself and has passed the validity and reliability test. To strengthen the study results, the authors gave tests to students to determine and measure students' understanding and success in learning listening skills. The test is created and uploaded via liveworksheet platform.

This study collects data by developing field information through a google form in the form of a questionnaire and also the pre-test given at the first meeting to determine the students' initial abilities, as well as the post-test given at the end after all learning was given to determine the effect of students' abilities on listening skills through the liveworksheet platform. The mechanism for collecting this information uses an instrument, which means using the method's name. The questionnaire format is in the form of questions with a total of 16 items. Then, before the questionnaire was distributed to students, the researcher tested the validity and reliability of the questions using SPSS 24.0, and all questions were declared valid. In the reliability of the questionnaire, it was found that the overall Cronbach Alpha Coefficient of the questionnaire was $(\mathrm{r}=0.605)$, and the overall Cronbach Alpha Coefficient of the tests given to students was $(\mathrm{r}=0.633)$, which can be stated that the level of internal consistency is acceptable. Thats means these questionnaires and tests can be used for research.

Field information in the form of a questionnaire is used because it is used to test, review, and find out the perceptions of each student regarding the use of the platform for the listening skill learning process from many respondents in an efficient and timely manner. After that, the researcher distributed questionnaires to all students who were used to doing tests using live worksheets during learning from home. Yin (2018) says that surveys using questionnaires can examine facts and depth on a raised phenomenon. Moreover, if a listening practice test accompanies the data collection, students independently. Therefore, the teacher carries out brainstorming to support understanding in listening by providing explanations accompanied by text in the form of information conveyed.

This process can make it easier for students to capture and practice the material. The material presented on this platform is through learning videos and includes practice questions with relevant material. Giving tests to students is carried out every week, which is carried out seven times during two months of online learning meetings. And also, on this platform, students and teachers can see the grades in real-time after the assignment collection. Then as a reference value, the teacher measures the students' listening skills using pre-test and posttest.

Therefore, a questionnaire consisting of 16 items is very helpful to find out students' experience in using live worksheets to balance the results of test scores that have been carried out. Before the two instruments were distributed, the author tested and analyzed them to ensure 
the validity of the quantitative instrument data. Phakiti (2015) stated using SPSS 24.0 software and noted that all were significantly valid and accurate to be distributed to students. In addition, Likert's responses to student perceptions expressed in the form of percentages obtained from online data collection were then processed and analyzed descriptively.

\section{FINDING AND DISCUSSION}

\section{Students listening skill ability}

Apart from the questionnaire, to find out students' success, it is also necessary to score from the tests that are given regularly. That can also be a reference to determine the increase in student understanding results. Creativity and exciting media are things that can show students' listening skills ability. Therefore, selecting this liveworksheet is an alternative for teachers and students in learning. In addition, the teacher provides pre-test and post-test to students with the aim of knowing the ability of students' listening skills through this platform. Then, the results of the pre-test and post-test were processed using the Paired Samples Test to state the results as listed below.

Table 1: Paired Samples Test

\begin{tabular}{|c|c|c|c|c|c|c|c|c|}
\hline & \multicolumn{5}{|c|}{ Paired Differences } & \multirow[b]{3}{*}{$\mathrm{t}$} & \multirow[b]{3}{*}{ df } & \multirow{3}{*}{$\begin{array}{l}\text { Sig. } \\
(2- \\
\text { tailed }) \\
\end{array}$} \\
\hline & \multirow[b]{2}{*}{ Mean } & \multirow{2}{*}{$\begin{array}{c}\text { Std. } \\
\text { Deviation }\end{array}$} & \multirow{2}{*}{$\begin{array}{c}\text { Std. Error } \\
\text { Mean }\end{array}$} & \multicolumn{2}{|c|}{$\begin{array}{l}95 \% \text { Confidence } \\
\text { Interval of the } \\
\text { Difference }\end{array}$} & & & \\
\hline & & & & Lower & Upper & & & \\
\hline $\begin{array}{ccc}\text { Pair } & \text { PRETEST } & \text { - } \\
1 & \text { POSTTEST }\end{array}$ & -2.44423 & .64304 & .08917 & -2.62325 & -2.26521 & -27.410 & 51 & .000 \\
\hline
\end{tabular}

From the test results in Table 1, it is known that the value of sig. (2-tailed) of $0.00<0.05$. So it can be concluded that there is a significant difference in the results of students' listening skills, which means that students have significantly their listening skills ability by using liveworksheets.

\section{Students perspective using liveworksheet}

This online-based platform called liveworksheet is a platform that has practical ease of access via smartphones or computers and is enjoyable to use as a medium for self-interactive assessment without self-correcting student answers. Another convenience that this platform has is that teachers or students do not need to download and without having to print out the exercises, so they are light to use. According to Cakrawati (2017), perspective is a view of a person's point of view that is different in every vision. Recognition of students' perceptions of the liveworksheet platform in learning was studied in a total of 52 participants. Students understand the video material and tests that have been made and then respond to the questionnaire. Liveworksheet also provides various conveniences to access this platform such as multiple choice answers, essays, short paragraphs, listening exercises, speaking exercises, inserting youtube links, and many other features provided to develop creativity in attracting interest and student learning in listening skills ability.

Therefore, the competency studied is how students perceive the use of liveworksheets to facilitate their listening skills. After that, based on the results of the questionnaire test results distributed to students, the data is processed and proven by the statistical analysis of normality tests using SPSS. The Kolmogorov-Smirnov normality shows the number sig based on the results table. 0.57 . It can be interpreted that the value of the data results shows the amount $>$ 0.05 and proves that the data is declared normal. So, from the results above, it can be seen that the distribution of the questionnaire distributed to students is expected. 
Result from the students' perspective responses show six indicators obtained, which are described below.
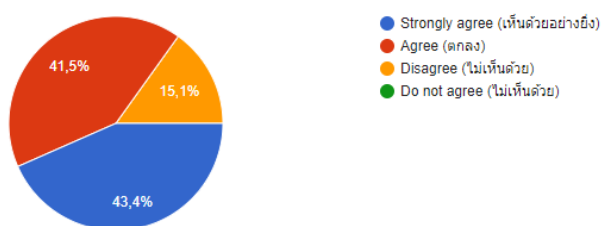

Figure 1. Do you agree that the liveworksheet used today is effective in the listening selecting this covid19 pandemic?

Studying from home makes students more limited in learning which is done online, especially network and media constraints that cause students to experience obstacles, significantly to students listening skill ability. However, based on a survey distributed to students at Ban KaengSriphum Juinor High School, 43.4\% of participants strongly agree that live worksheets are an effective platform for listening skills.
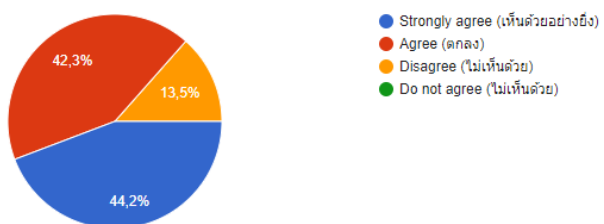

Figure 2. Do you agree that the current liveworksheet should be preserved for listening?

The learning media used in this era have a significant impact on the implementation of teaching and learning activities. That causes teachers to choose media with many conveniences, such as this liveworksheet. Therefore, $44.2 \%$ of students strongly agree that the liveworksheet platform needs to be maintained for listening skills.
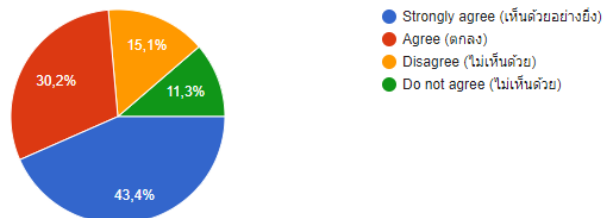

- Agree (ดกลง)

- Disagree (ไม่เห็นด้วน)

Figure 3. Is the media used today in accordance with what is needed in the listening process?

As many as $43.4 \%$ of students strongly agree with this review because the ease of access presented on the liveworksheet platform provides the facilities needed in the listening process according to what students expect in learning listening skills.
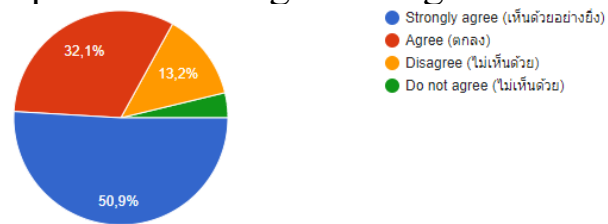

Figure 4. Do you agree that listening is an important lesson to learn?

Listening is an important thing that everyone, especially students, must learn. That is because every action is needed to understand or capture information. Therefore listening is the primary learning that must be obtained, so $50.9 \%$ of students strongly agree that listening lessons are essential.
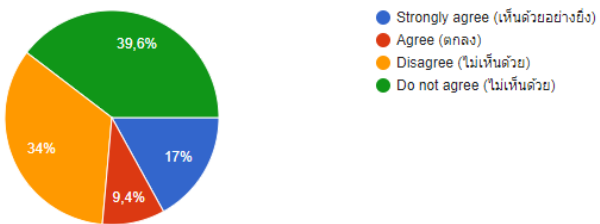

Figure 5. Do you agree that liveworksheet are challenging to understand media in listening learning? 
In this statement, $39.6 \%$ of students strongly disagree that the live worksheet platform is challenging to understand because students state that their live worksheet has easy access to be used in listening skills.

From the description of the diagram above, it can be seen that the students' questionnaire responses to the perspective of using the liveworksheet platform for listening skills are said to be able to help students in their listening skills ability. This platform provides a lot of ease of access. Its, it is that most of the students agreed that the liveworksheet is an effective platform. So, most of the students' perspectives stated that they did not agree that the liveworksheet is a platform that is difficult to understand in listening skills. In addition, out of 52 students tend to agree that using the liveworksheet platform can help in students' listening skills ability because attractive and creative designs can help their enthusiasm for learning so that they achieve increased and satisfying grades. Therefore, the students stated that they agreed that the liveworksheets need to be maintained for listening learning to their listening skills ability, Rhosyida (2021).

\section{CONCLUSION}

The results of the above description, during the covid19 pandemic, sophisticated and exciting learning media are needed in today's technology that makes it easier for students and teachers to make effective and successful learning even in different places, such as using the liveworksheet platform. This liveworksheet is an online-based platform that can be done anywhere without being bound by time and provides various features for easy access that can be adapted to the topic to be delivered along with exercises in the same room; one of these features that can be used is listening. Listening is also an essential material in every way. Therefore, teachers can design learning objectives and good preparation in this platform to understand the material well and increase their listening skills ability. This is also evidenced by the results of the students' pre-test and post-test which showed an increase in their listening skills ability. That is stated in the results of the SPSS Paired Test with a significant value of 0.00 , which means that there is success in students' listening skills.

In addition, the questionnaire survey results distributed to 52 participants said that the platform's convenience helped their ability to their listening skills ability. This means that students can understand the material and can do the exercises easily. Most of the students agreed and strongly agreed that the liveworksheet had helped them to their listening skills ability. In addition, students also agree that this platform is a learning medium that is expected and needs to be maintained during this pandemic because they liveworksheet is an effective platform, easy to understand, and easy to use or access. Listening skills are also essential learning, and students find suitable media with a good impact on learning in this era. This platform is highly recommended for teachers as an interactive learning medium, especially in listening. In this study, the researcher found no shortcomings in the use of liveworksheet because the platform can help students listening skills ability by using the platform.

The suggestion from the researcher is that before the assignment to students, it is better to provide an explanation of the material in the form of a video, after that add an audio listening assignment. And the recommendation from the researcher is to provide an attractive and different appearance in each exercise, so that students' interest in learning increases and provides maximum results in each meeting.

\section{ACKNOWLEDGEMENTS}

The author would like to thank Mr. Slamet Asari as the lecturer and to Ban KaengSriphum Junior High School Thailand which support to this study. 


\section{REFERENCES}

Abarquez, A. (2021). Lens of Language and Literature Programs in the New Norm Educational Setting amidst Pandemic. 7, 382-394.

Abidin, Z., Mathrani, A., Hunter, R., \& Hunter, R. (2021). Teaching with technology : a lesson from social participation in an online learning community. Technology, Pedagogy and Education, 00(00), 1-12. https://doi.org/10.1080/1475939X.2021.1884128

Adedoyin, O. B., \& Soykan, E. (2020). Covid-19 pandemic and online learning: the challenges and opportunities. Interactive Learning Environments, 0(0), 1-13. https://doi.org/10.1080/10494820.2020.1813180

Andry, J. F., \& Tjee, C. (2019). Analisis Minat Mahasiswa Mendengarkan Aplikasi Musik Berbayar dan Unduhan Musik Gratis. Journal of Business and Audit Information System, 2(2), 9-15. http://dx.doi.org/10.30813/jbase.v2i2.1727

Arief, S. (2020). Pembelajaran Online Dimasa Pandemi Covid-19. Jurnal Sipatokkong BPSDM Sulawesi Selatan, 01(04), 336-339.

Bozorgian, H. (2014). The Role of Metacognition in the Development of EFL Learners ' Listening Skill. December, 37-41. https://doi.org/10.1080/10904018.2013.861303

Cakrawati, L. M. (2017). Students 'Perceptions on the Use of Online Learning Platforms in Efl Classroom. 1(1), 22-30.

Cheon, B. J., \& Grant, M. (2009). Web-based Assessment Tool for Communication and Active Listening Skill Development. 53(6), 2009.

Flipped, P., \& Di, C. (2021). Mengoptimalkan Penilaian dengan Liveworksheet pada Flipped Classroom di SD. Jurnal Taman Cendekia, 05(01), 568-578.

Fournier, R. K. (2011). The new dimension of self-directed learning in an open networked learning environment. International Journal of Self-Directed Learning, 7(2), 1-20.

Goh, C. C. M., \& Vandergrift, L. (2021). Teaching and Learning Second Language Listening. New York

Gusty, S., Sulaiman, O. K., \& Manuhutu, M. A. (2020). Belajar Mandiri: Pembelajaran Daring di Tengah Pandemi Covid-19. Yayasan Kita Menulis

Hubbard, K. R. (2010). Pervasive CALL learner training for improving listening proficiency. In M. Levy, F. Blin, C. Siskin, \& O. Takeuchi (Eds.),. New York: Routledge.: International perspectives on computer-assisted language learning.

Ismail, S., Zaim, M., Mukhayyar., \& Gistituati, N. (2020). An Analysis on Learning Condition in Developing Listening Comprehension Model by Using Social Media for English Student. J-SHMIC : Journal of English for Academic, 07(01), 33-42.

Jalaluddin, R. (2004). Psikologi Komunikasi. Bandung: PT. Remaja Rosdakarya.

Jewitt, C., Clark, W., \& Hadjithoma-garstka, C. (2011). The Use of Learning Platforms to Organise Learning in English Primary and Secondary Schools. Learning, Media and Technology, 36(4), 335-348.

Kop, R., \& Fournier, H. (2011). New Dimensions to Self-directed Learning in an Open Networked Learning Environment. International Journal of Self-Directed Learning, $7(2)$.

Lai, C., Shum, M., \& Tian, Y. (2016). Enhancing learners' self-directed use of technology for language learning: the effectiveness of an online training platform. Computer Assisted Language Learning, 29(1), 40-60. https://doi.org/10.1080/09588221.2014.889714

Listiyaningsih, T. (2017) . The Influence of Listening English Song to Improve Listening Skill in Listening Class. Academia, 1(1), 35-49.

Memilih, K., \& Tinggi, P. (2019). Persepsi Siswa Terhadap Pendidikan Tinggi dan 
Kecenderungannya Memilih Pendidikan Tinggi Lanjutan (Studi pada Siswa Kelas XII SMA Negeri 3 Luwu Tahun Ajaran 2017/2018). Universitas Negeri Makassar.

Mukti, N. I., Rochmawati, Senta, A. N., Utami, L. C. W., \& Hanim, Z. A. (2021). Promoting Willingness to Communicate in Improving Students' Second Language Acquisition Through Liveworksheets.Com. JEASP Journal of English for Academic and Specific Purposes, 4(1), 128-141.

Nor, H. (2014). The Techniques in Teaching Listening Skill. Journal on English as a Foreign Languange, 4(1), 41-51.

Pahamzah, J. (2021). Improving Students' Listening Skill and Vocabulary Masteryn Through Contextual Teaching and Learning (CTL) by Using Online Learning for Senior High School. International Journal of English Language and Linguistics Research, 9(4), 4555.

Phakiti, A. (2015). Quantitative research and analysis. In Paltridge, B., \& Phakiti, A.(Eds). London, UK: Bloomsbury: Research method in applied linguistics (pp.28-48).

Puspaningtyas, N. D., \& Dewi, P. S. (2020). Persepsi Peserta Didik terhadap Pembelajaran Berbasis Daring. Jurnal Pembelajaran Matematika Innovatif. 3(6), 703-712. https://doi.org/10.22460/jpmi.v3i6

Rachmawati, M., \& Yolanda, F. (2020). Perspektif Siswa terhadap Pembelajaran Daring di Masa Pandemi Covid 19. Jurnal Edukha, 1(2), 205-210.

Routledge. (2011). Routledge Studies in Computer Assisted Language Learning Edited. Taylor \& Francis The.

Rubin, J. (1994). A Review of Second Language Listening Comprehension Research. The Modern Language Journal, 78(2). https://doi.org/10.2307/329010

Saleh, A. (2020). The Impact of COVID-19 Pandemic on Modes of Teaching Science in UAE Schools. 11(20), 110-115. https://doi.org/10.7176/JEP/11-20-13

Siradjuddin, S. (2020). An Analysis of University Students 'Perspective on Online Learning in the Midst of Covid-19 Pandemic. 53(May), 125-137

Vidal, C. P., López-serrano, S., \& Thomas-wilhelm, D. J. (2018). Learning context effects. Creative Commons Attribution.

Wang, C., Shannon, D. M., \& Ross, M. E. (n.d.). Students ' characteristics, self- regulated learning, technology self-efficacy, and course outcomes in online learning. December 2014, 37-41. https://doi.org/10.1080/01587919.2013.835779

Watson, K. W., Barker, L. L., \& Barker, L. (2012). Listening Assessment : The Watson-Barker. 4507(May). https://doi.org/10.1080/10904018.1988.10499095

Winslen, A., \& Wallace, G. L. (2002). Behavior Problems and Social Skills in Preschool Children: Parent - Teacher Agreement and Relations With Classroom Observations. Early Education and Development, 13(1), 41-58

Yin, R. K. (2018). Case study research and applications: design and methods. Los Angeles, UK: SAGE.

Yulianto, D., \& Mujtahid, N. M. (2021). Online Assessment during Covid-19 Pandemic: EFL Teachers' Perspectives and Their Practices. Journal of English teaching, 7(2), 229-242. https://doi.org/10.33541/jet.v7i2.2770

Zboun, J. S., \& Farrah, M. (2021). Student's Perpective of Online Language Learning During Corona Pandemic : Benefits and Chalenges. Indonesian EFL Journal (IEFLJ, 7(1). 